\title{
RENT PARTIES, OLD SETTLERS AND JITTERBUGS: THE EVERYDAY LIFE OF AFRICAN AMERICANS AFTER THEIR EXODUS TO NORTHERN CITIES AS PRESERVED IN ORAL HISTORIES, 1917-1945
}

\author{
Patryk Mamczur \\ http://orcid.org/0000-0001-7833-9694 \\ Jagiellonian University, Kraków
}

\begin{abstract}
The author aims to portray the Great African-American Migration by showing the everyday life of the migrants. Starting from presenting the different ways of migrating North, he later describes conditions in which the migrants lived in the Northern cities, relationships with their non-Black neighbours and with the so-called Old Settlers (meaning African Americans who had lived in the North before the Great Migration), their economic struggle, ways of overcoming the problems, as well as the distinctive culture which the migrants eventually developed, and the ferment which these cultural changes created in the whole American society. The narration is based mostly on the oral histories collected from numerous Northern cities: Albany (New York), Chicago (Illinois), Cincinnati (Ohio), Cleveland (Ohio), Detroit (Michigan), Milwaukee (Wisconsin) and New York (New York).
\end{abstract}

Keywords: United States of America, American history, American culture, African-American history, African-American culture, migration, everyday life, oral history.

The attitude of the average white New Yorker to Harlem is one of tolerant amusement. He thinks of it as a region of prosperous night clubs; of happy-go-lucky Negroes dancing all night to jazz music.

New York Herald Tribune, $1930^{1}$

One might say that the history of the United States of America is, in fact, a history of ongoing migrations. However, even in the course of the American history, the

1 As quoted by: G. Osofsky, Harlem: The Making of a Ghetto, New York 1966, p. 151. 
Great African-American Migration, lasting from the year 1917 to the 1960s, was an extraordinary event - both in terms of numbers, as c. 6-7 million Black Americans travelled from Southern states to Northern cities, and in terms of major social and cultural changes that followed the migration. This article aims to portray the Great Migration, however, not from the perspective of those country-wide changes but rather showing the everyday life of African-American migrants.

We will begin in the year 1917 and end in 1945 - both years connected to the World War I and World War II and thus, as we will observe, being crucial to the history of the Great Migration. Starting from the different ways of migrating itself, we shall describe conditions in which the migrants lived in the Northern cities, relationships with their non-Black neighbours and with the so-called Old Settlers (meaning African Americans who had lived in the North before the Great Migration), their economical struggle, ways of overcoming the problems, as well as the distinctive culture which the migrants eventually developed and the ferment which this cultural changes created in the whole American society.

In order to present the everyday life of the migrants, we will use adequate sources, mostly oral histories - both those collected during the described years (like interviews with migrants and reports of eye witnesses preserved in the Federal Writers' Project archive in the Library of Congress) and those recorded after a few decades (e.g. oral histories aggregated by Elaine Latzman $\mathrm{Moon}^{2}$ ). The analysed stories come from following Northern cities, i.e.: Albany (New York), Chicago (Illinois), Cincinnati (Ohio), Cleveland (Ohio), Detroit (Michigan), Milwaukee (Wisconsin) and New York (New York). Apart from that, we shall also make use of secondary sources, e.g. newspaper articles and statistics, which will let us confront the individual perspectives with a broader picture.

While we will focus on the everyday life of African-American migrants - presenting experiences of particular people, preserved in oral histories - we still should not forget about the broad, theoretical approach to the subject of migration. An article which can help us with that, now considered classic, is $A$ Theory of Migration by American scholar Everett S. Lee. When analysing the factors in the act of migration, Lee defined two most important groups: factors associated with the place of origin and those associated with the area of destination. In general, the more repulsive the factors at the place of origin and more attractive the factors at the place of destination, the more willing a person to migrate. ${ }^{3}$

However, as Lee points out, "knowledge of the area of destination is seldom exact ..., thus there is always an element of ignorance or even mystery about ... a new area." What is more, while the migration is based on factors at origin and destination, "a simple calculus of +'s and -'s does not decide the act of migration. The balance in favour of the move must be enough to overcome the natural inertia," the ever-existing fear of change. And, finally, describing the area of origin and the area of destination is

2 E. Latzman Moon, Untold Tales, Unsung Heroes: An Oral History of Detroit's African American Community, 1918-1967, Detroit 1994.

3 E. S. Lee, “A Theory of Migration,” Demography 1966, vol. 3, no. 1, pp. 49-50. 
not everything, as "between every two points there (also) stands a set of intervening obstacles."

Keeping in mind Lee's observations, we will try to answer a few important questions connected with the Great African-American Migration and the everyday life of Black migrants. What were the reasons behind the decision of African Americans to move North? Which obstacles did they have to overcome during their journey? How did their knowledge of the area of destination look when compared with the reality? How were the migrants perceived by other people living in the cities? What were their strategies of overcoming social and economical struggle? In what way did their culture change because of the migration? And, finally, were these cultural changes exclusive to the group itself or were the consequences more far-reaching?

\section{JOURNEY TO THE NORTH}

The beginnings of the Great African-American Migration are directly connected to the World War I. While conditions of the so-called war economy required more and more people to work in Northern factories, many young and White men (i.e. those who had worked in the factories before) joined the army, thus leading to the employment of the groups which had been somehow marginalised before - most notably, women and African Americans. For many Blacks from the Southern states the opportunity was too good to miss. They were wishing to improve not only their economical status but also the social one (it must be remembered that while the slavery had officially ended in 1865 , the racial segregation was still present because of the so-called Jim Crow laws) and they believed that migrating North was the ideal way of achieving this goal.

However, travelling to Chicago or Detroit was not as easy as one may have thought. There were three basic ways in which African Americans migrated to the North. Firstly, Northern factories sent their representatives, so-called labor agents, down South in order to recruit people to work. Those who agreed were offered a train ride to one of the Northern cities. ${ }^{5}$ Many took the opportunity, however, some of them decided that being tied down by working for a particular employee was not the ideal situation. M. Kelly Fritz, who travelled to Detroit, described it as follows:

Labor agents would go around town and recruit you, and you got a free ride to this part of the country. What happened is they would get on those cars; and they were supposed to come to

Detroit ... because they were building a new General Motors plant then. And some of them

4 Ibid., pp. 50-51.

5 J. W. Trotter Jr., Black Millwaukee: The Making of an Industrial Proletariat, 1915-1945, Urbana-Chicago 1985, p. 46; J. R. Grossman, Land of Hope: Chicago, Black Southerners, and the Great Migration, Chicago-London 1991, pp. 68-73. 
would get off other places. So sometimes when they got where they're going, they didn't deliver many people. ${ }^{6}$

Such people were not the only ones wishing to take advantage of the whole situation, as - on the other hand - various impostors visited Southern states promising well-paid jobs, transport to the North and even clothes. They demanded advanced payment and then quickly disappeared. We can see that it was a serious problem, as the Chicago Defender, which acted as a popular source of advice for many Black Southerners wishing to travel North, published actual warnings: "There are number of agents in the south that are collecting money from members of the Race who are planning to leave for the north. No one should pay any one to leave."

The second way of travelling North, probably the safest one, meant organising the travel by yourself. While not everyone could afford that, some succeeded and many of those successful trips depended on local communities. James R. Grossman, a scholar interested in the Black diaspora in Chicago, cites an example of Robert Horton, a barber from Hattiesburg, Mississippi. He organised a travel of c. 40 people, both relatives and friends, and even managed to secure a group discount from the railroad. ${ }^{8}$

The last way of migrating North was, in contrast, the least safe and the least lawful one. It was the so-called hoboing, i.e. travelling (by train) without paying. James Boggs, who was such a hobo, explained what it looked like:

I came (to Detroit) in 1937, and I came here on the freight train, as most people were doing those days. ... (It was) the way people would travel mostly at the time - you were a hobo. Black and white and everything else ... Myself and one of my friends from Alabama got on the freight train and hoboed up north. We had nothing but what we had on our backs, that's all. ... I had about fifty cents, he had about fifty cents. ${ }^{9}$ We ran out of money the second day. ... Sometimes you'd get on the freight train (and) there'd be fifty people on the freight train scattered all over ... the big thing you had to worry about was, when you come into a town and the freight train slowed down, everybody jumped off and walked around the town to catch the train when it would leave out the other end of town. (Because) Down South in Tennessee, if they'd catch you (hoboing), they'd put you on a peanut farm to pick peanuts. ${ }^{10}$

As we can observe, despite the risks of hoboing, such means of transport were very popular - especially in times of the Great Depression (Boggs travelled to Detroit in 1937). However, even if someone arrived to one of the Northern cities without encountering serious problems, it did not mean the end of the struggle.

6 E. Latzman Moon, Untold Tales, p. 80.

J. R. Grossman, Land of Hope, p. 73.

8 Ibid., pp. 66-67.

9 According to the Measuring Worth project, the relative value of 1 USD during the described era (i.e. 1920s-1940s) equals approximately 15 USD of 2016. See: www.measuringworth.com [access: 29.01.2018].

10 E. Latzman Moon, Untold Tales, pp. 149-150. 


\section{LIFE IN THE SOUTH END}

From the very beginning of the Great Migration, the Black Southerners arriving to the Northern cities had virtually no choice in terms of selecting a neighbourhood in which they were supposed to live. Each city had a district, usually in its oldest part, near the river, where a ghetto ${ }^{11}$ was established and those districts had peculiar names - some neutral, like the South End in Albany, other pretty meaningful, just like the Chicago's Black Belt. ${ }^{12}$

This ghettoisation, as it is sometimes called, existed for a number of reasons. Firstly, many migrants themselves simply preferred to stick together, as they often knew each other, being a family or coming from the same area in the Southern states. In many relations we can find histories of brick houses in Northern cities inhabited by people who arrived there from the same town, e.g. in Alabama. ${ }^{13}$

Secondly, for many Black Southerners, renting a house outside of a ghetto was impossible because of financial reasons. James Stamper and his family migrated to Albany in 1930 from Atlanta, Georgia, where they had lived in a big, ten-room house. However in the North situation was different:

You just couldn't find anything like that and if you found it, they wouldn't rent it to you. It was impossible to buy; we just didn't have the money. It was one of the most discouraging experiences that I can remember. ... My mother and all of us - there were ten of us, five boys and five girls - we were just not able to find housing. We lived with my uncle for a while, until we were able to find housing. When we did, it was ... rental; we did not buy a house until $1950 .{ }^{14}$

What is more, even after securing sufficient funds, renting or buying a house outside of a ghetto was a problem - because of various restrictions and "gentlemen's agreements" prohibiting the sale of properties to African Americans. In the early 1940s, George Brawley, a Black Attorney from Milwaukee, carried out a study and found out that " 90 percent of the plats filed (with the Milwaukee County Register of Deeds Office) after 1910 contained some restrictions prohibiting the sale of property to Blacks." ${ }^{15}$ Relations from other cities build up a very similar picture. ${ }^{16}$ And, last but not least, we also need to mention that the ghettoisation of Black families was ben-

11 The term 'ghetto' is used throughout the article with respect to the African-American tradition of calling districts inhabited by Black citizens that way - tradition reflected not only in informal speech and in popular culture but also in academic writing (e.g.: G. Os ofsky, Harlem: The Making of a Ghetto).

12 B. A. Bunch-Lyons, "No Promised Land": Oral Histories of African-American Women in Cincinnati, Ohio," OAH Magazine of History 1997, vol. 11, issue 4, p. 12; J. A. Lemak, "Albany, New York and the Great Migration," Afro-Americans in New York Life and History 2008, vol. 32, issue 1, pp. 48, 52-53; G. Osofsky, Harlem, p. 127; J. R. Gross man, Land of Hope, pp. 123-126.

13 K. L. Phillips, "'But It Is a Fine Place to Make Money': Migration and African-American Families in Cleveland, 1915-1929," Journal of Social History 1996, vol. 30, issue 2, p. 403; G. O so fsky, Harlem, pp. 128-129.

14 J. A. Lemak, “Albany, New York and the Great Migration,” pp. 54-55.

15 J. W. Trotter, Black Millwaukee, p. 71.

16 E. Latzman Moon, Untold Tales, p. 58; J. A. Lemak, "Albany, New York, and the Great Migration," pp. 54-55; G. Os ofs ky, Harlem, p. 131. 
eficial for some African Americans. Namely, for local politicians who wanted their voters to be concentrated in one district and for Black businessmen who preferred not to loose their customers. ${ }^{17}$

The ghettoisation led to a situation described as a "colored tax." As the flat owners knew that Black migrants had virtually no other option and simply had to live in a particular district, they could raise the rent - all in all, more Black Southerners were arriving all the time, so the demand was not decreasing. ${ }^{18}$ In 1927, African Americans living in Harlem had to pay for a three-room flat 8 dollars more than an average New Yorker (i.e. 42 dollars a month). It meant that they were spending $30-50 \%$ of their money on the rent, while for other people living in the "Big Apple" it was only c. $20 \% .{ }^{19}$

However, if we imagined that only African Americans lived in the South End, the Black Bottom and other similar districts, we would be wrong. For example, in the ghetto in Milwaukee, the Black migrants formed only $22 \%$ of the population. ${ }^{20}$ Who also lived there then? Other marginalised groups, often immigrants from Europe. What is very interesting, all those groups demonstrated a peculiar solidarity, as explained by Dorothy Lawson from Detroit:

At one neighbourhood we lived in, there were mixed families. There were Italians, Polish, Negroes. It was just like one big happy family (and) my best friend was a Polish girl. One day she would come to my house for lunch, and the next day I would go to her house ... We would be eating the same thing (anyway), because it was during the depression ... When everybody had the same thing on their table, you couldn't think you were better ... You used the piece of cardboard from the same box to cover that hole (in your shoe). ${ }^{21}$

While different nations living in ghettos tried to cohabitate, at the same time, they were opposed to people from other districts. And again, the reasons for that were not racial but rather economical. As Geneva Conway from Albany recalled:

In the South End it was the Blacks, the Jews, and the Italians. I don't know what it was about us; maybe it was because all of us were so poor. We did not have time to fight one another as races - we had to survive ... All of us kids, if we fought one another, we fought because you were from uptown. We didn't fight you because you were white. If you came from below the Strand Theater, you were in trouble ... We didn't care what color you were, you were in trouble. ${ }^{22}$

17 J. R. Grossman, Land of Hope, p. 130, 144; J. W. Trotter, Black Millwaukee, pp. 71-72.

18 K. L. Phillips, “'But It Is a Fine Place to Make Money': Migration,” p. 397; J. W. Trotter, Black Millwaukee, pp. 67, 70; B. A. Bunch-Lyons, “"No Promised Land.' Oral Histories,” p. 12; F. Byrd, Harlem Rent Parties, MSS55715: BOX A721, Library of Congress, pp. 1-2, 4.

19 G. Osofsky, Harlem, pp. 136-137.

20 J. W. Trotter, Black Millwaukee, p. 67.

21 E. Latzman Moon, Untold Tales, p. 117.

22 J. A. Lemak, “Albany, New York, and the Great Migration," p. 53. 


\section{NEW UNCLES AND RENT PARTIES}

As we have already mentioned, despite the fact that the Great Migration began with the trips of young men (just like many migrations throughout the history), soon they were joined by other family members. Because of that, there were no drastic changes in the structure or hierarchy of the migrant families. According to the research of Kimberley Phillips, the family relations were virtually the same as in the South - fathers remained heads of families, there was no rise in the number of single mothers and if one could find a woman raising her children alone, it was not because of having illegitimate babies or the father leaving them but rather of the father passing away (just like it had been before, down South). ${ }^{23}$

The most important change was the one relating to the youngest children. In the South, it was usually a mother who was responsible for taking care of them but in the North women had to spend a lot of time working away from home, therefore they needed some help in raising the youngest ones. Sometimes the support was provided by other family members (e.g. older siblings, grandparents) but very often the ones who offered help were not related to the family at all. As most of the buildings in ghettos were very old, the flats were too big for an average migrant family. Because of that, they invited people from outside - so-called boarders (or lodgers). In 1930, 27\% African-American households in Albany had boarders and in the same year in Cleveland it was c. $33 \%{ }^{24}$ Such a situation was a chance to split the high rent but it also had a social aspect in it - in many oral histories there are mentions of "aunts" or "uncles" who took care of the children when the real family members were away working. ${ }^{25}$

Another peculiar way of earning some money in order to pay the rent was organising so-called rent parties. Once a week, usually on a Saturday evening, families invited both friends and strangers to come to their flat. For a small admission fee, the guests could chat, listen to music (often played live by friendly musicians), dance, eat home-made food and drink. Some rent parties were even advertised in press:

If you're looking for a good time, don't look no more,

Just ring my bell and I'll answer the door.

Southern Barbecue

Given by Charley Johnson and Joe Hotboy

While the rent parties were mostly a way of coping with the harsh reality of the ghetto life and with the high rent, people outside the ghetto treated it rather as a peculiar novelty - a way in which Black migrants simply entertained themselves. ${ }^{26}$

${ }^{23}$ K. Phillips, “'But It Is a Fine Place to Make Money’: Migration,” p. 399.

24 J. A. Lemak, "Albany, New York, and the Great Migration," p. 50; K. Phillips, “"But It Is a Fine Place to Make Money': Migration,” p. 401.

25 S. Robertson, S. White, S. Garton, G. White, "The Harlem Life: Black Families and Everyday Life in the 1920s and 1930s," Journal of Social History 1/2010 (44), pp. 101-102; K. Phillips, "But It Is a Fine Place to Make Money': Migration,” pp. 401-402.

26 G. Osofsky, Harlem, p. 139. 
One could think that a part of the high rents was spent on repairing the old brick houses. In fact, it was the other way around - because of the aforementioned high demand, landlords did not have to care about such things. Let us quote an excerpt from a survey made by the National Urban League in 1928 in Albany:

Family \#29. Toilet outside and out of order. Landlord will not fix. Ceiling down. Doors don't shut. Kitchen always cold ... In this district many houses are untenable; brick walls are cracked and in need of painting; many of the rooms need artificial light all day long; toilets connect with kitchen, often with no door in between. Halls, yards, toilets are shared by many families. ${ }^{27}$

As we can see, the situation was very far from good. On the other hand, we must realise that the conditions of living, even in the oldest brick houses, were still better than in the simple shacks down South. ${ }^{28}$ Finally, there was virtually no homelessness, as everybody could find some place to live - if not by renting a flat, then by securing place in somebody else's flat as a boarder. ${ }^{29}$

\section{RED CIRCLE AT THE TOP}

One of the very first things to do after moving to a Northern city, was to find a job. In fact, Black Southerners often travelled up North with a specific factory in their mind. In Detroit, for example, it was the Ford's automobile company. James Boggs the very same who travelled to Detroit by freight train, hoboing - decided to migrate because he had heard from his relative that there is an opportunity to find a job there:

(There) weren't many black working in the auto industry at all. Ford was the one where blacks worked, and they worked in the foundry. I used to have a cousin working at Ford. Even at that time, they was (sic) big shots. Big shots because they was always the ones who had a paycheck, getting about twenty-five to twenty-six dollars a week. At that time, it was lots of money. Most people had them (sic) ten-, eleven-, and twelve-dollar-a-week jobs. ${ }^{30}$

The choice was, however, very limited, especially for Black women. When reading oral histories, we have an impression that most of them worked as housekeepers - and statistical sources confirm it, as, for example, in Milwaukee $62 \%$ of AfricanAmerican women were performing this job. ${ }^{31}$ The situation changed a little during World War II when many of them went to work in factories. ${ }^{32}$ They were somehow substituting their husbands, as it was the factory work that was the major source of payment for Black men - mostly in the automotive and meat-packing industries. Men

27 J. A. Lemak, “Albany, New York, and the Great Migration,” pp. 53-54.

28 J. R. Grossman, Land of Hope, pp. 135-137.

29 S. Robertson et al., "The Harlem Life," pp. 106, 116.

30 E. Latzman Moon, Untold Tales, p. 150.

31 J. W. Trotter, Black Millwaukee, p. 51.

32 J. R. Grossman, Land of Hope, pp. 184-185; J. A. Lemak, "Albany, New York, and the Great Migration," p. 53. 
had, however, a few more options than women. Some of them secured a job as a janitor, elevator operator, docker or driver. ${ }^{33}$

Regardless of the sector in which a particular Black migrant was working, "colored job" (or "colored work") was an on-going expression back then. It usually meant jobs for so-called unqualified workers (in 1930, 78\% of Black men in Albany were working as such ${ }^{34}$ ) and that meant the worst-paying job. While there were no de jure Jim Crow laws in the North, such practices meant that African-American migrants were not treated equally in the everyday life. You were not earning less because you were Black, however, you were considered an unqualified worker because of that. And, in the end, it meant the same thing. ${ }^{35}$ James Stamper from Albany experienced this problem first-hand:

I applied many times (at the General Electric Company) and they would tell me that they kept these applications on file for six months, and they would say (to me:) come back in six months if you don't hear from us and we will have you apply again. And I applied many times, I (would) go down and they would say, "Sorry, we're not hiring." ... I went back time and again until about 1942 ... (and) finally they told me there was a job available as a material handler ... When they decided to give me the job, they called me in, and they had all of my applications clipped right together. At the top of the application there was a red circle: AMERICAN NEGRO. ... In those days it seemed to have meant so much more to them who you were rather than what you were going to do for the company. ${ }^{36}$

Why was this red circle so important? Northern businessmen believed that African-American migrants were not suited for more demanding factory jobs. They looked at Black Southerners as lazy, unreliable and always coming late. ${ }^{37}$ While, of course, such prejudices were not true, Northerners were right about one thing - migrants from South were simply used to different kind of work. Back in the rural areas of the United States, on plantations, there were times of hard work but also times of leisure (e.g. in the winter) when not much had to be done. What is more, the pace of work was often somehow elastic - an exemplification of which was the popular, Southern tradition of work songs which helped to set the tempo. In the industrial reality of Northern cities, one had to work hard during the whole year and, of course, there was no room for adjusting the work pace, as the tempo was set by factory machines. $^{38}$

Yet another reason for not hiring Black migrants for some jobs was that the employers were afraid that their clients would not like to have a contact with AfricanAmerican workers. ${ }^{39}$ It was a common practice to hire Blacks as bus drivers but not

33 B. Burke, Elmer Thomas, MSS55715: BOX A707, Library of Congress, p. 4; G. Osofsky, Harlem, p. 137; J. R. Grossman, Land of Hope, pp. 183-184.

34 J. R. Grossman, Land of Hope, p. 185.

35 J. W. Trotter, Black Millwaukee, p. 54; G. Osofsky, Harlem, p. 137.

36 J. A. Lemak, "Albany, New York, and the Great Migration," p. 61.

37 J. W. Trotter, Black Millwaukee, pp. 55, 61; J. R. Grossman, Land of Hope, pp. 195, 198.

38 E. Scott, “Additional Letters of Negro Migrants," Journal of Negro History 1919, vol. 4, no. 4, p. 458; B. Burke, Elmer Thomas, p. 5; J. R. Grossman, Land of Hope, pp. 181, 191-193; E. Latzman Moon, Untold Tales, p. 130.

39 J. R. Grossman, Land of Hope, p. 206. 
as conductors (ticket inspectors). And even some drivers had to deal with prejudice. James T. Jenkins from Detorit recalled an interesting story:

You drove up to a corner on the bus and opened your doors, and they would turn their back and say, "I don't ride with niggers." We used to laugh about it. ... "Well, you better come on and ride with me. The one behind me is blacker than I am." ${ }^{40}$

There was one more group of Northern citizens that was afraid or even ashamed of Black migrants from the South - and those were other African Americans, those who had been living in the North for a long time, often called Old Settlers. They believed that their cousins from Southern states should change many of their habits, published newspaper articles on that subject and printed leaflets. Let us quote one of them, issued by the Negro Urban League in Chicago:

Do not carry out loud conversations in street cars and public places ... Do not think you can hold your job unless you are industrious, sober, efficient and prompt ... Become an active member in some church as soon as you reach the city. ${ }^{41}$

\section{HERE COME THE JITTERBUGS}

Old Settlers, when talking about their fellow African Americans coming from South, commented not only on their work habits. They were also ashamed of their everyday customs, like wearing shawls (headscarfs) by women, going to local shops in slippers or eating watermelons in public. ${ }^{42}$ They did not like Southern culture either, e.g. the music which Southerners brought with them. According to Paul B. Shirley from Detroit, "the blues and jazz was controversial then. A lot of people didn't want jazz in their houses because (they believed that) jazz came from whorehouses." ${ }^{43}$

However, the situation soon began to change. As Southern customs mixed with Northern opportunities and the will to pursue the American Dream met with social obstacles, African-American migrants slowly started creating a new, urban culture. A culture which soon turned out to be interesting for people living outside of the ghetto. The first sign of these changes was arguably the so-called Harlem Renaissance period. In the 1920s, some of the posh New Yorkers realised that Harlem was inhabited not only by Black factory workers and housekeepers but also Black musicians, writers, painters and other artists. However, the White enthusiasts looked at this Black

40 E. Latzman Moon, Untold Tales, p. 209.

41 J. R. Grossman, Land of Hope, p. 147.

42 M. Swen son, Southern Customs, MSS55715: BOX A724, Library of Congress; J. R. Gross man, Land of Hope, pp. 150-152.

43 E. Latzman Moon, Untold Tales, p. 49. 
culture in a peculiar way, using adjectives like "primitive" or even "jungle." ${ }^{44}$ One White patron informed another about an upcoming artistic event:

There will be present a few artistic Negroes. It's really the thing! They recite with such feeling and when they sing - such divine tones. Imagine: a colored person playing Debussy and Chopin! ${ }^{45}$

As we can see, it was probably not the music itself that was important for the patrons but rather the colour of the performers' skin. The Harlem Renaissance ended as quickly as it had started but such a way of thinking about the new AfricanAmerican culture prevailed. It became obvious later, in the 1930s and 1940s, when another fashion emerged. The blues music, brought from the Southern states, began to change. Acoustic guitars were replaced by electric ones, which then were accompanied by drums, double bass (later electric bass guitar) and amplified harmonica (which operated as a pocket version of a brass section known from big band music). This style, quickly dubbed rhythm and blues or urban blues, slowly started to gain popularity among white listeners - in 1938 and 1939 John Hammond organised two "From Spirituals to Swing" concerts at New York's Carnegie Hall, which were billed as "an evening of American Negro music." Nigel Williamson considers them "seminal moments in the march of the blues into mainstream of white American culture." 46

White listeners of blues and jazz music, sometimes called "jitterbugs" (a name derivate from the dance which was popular among them), started acting similar to the patrons of the Harlem Renaissance era. They began to visit ghettos and local clubs. Those who were less aware, attended venues where the performers were the only Black people, the audience being all White. ${ }^{47}$ The more hip jitterbugs, however, visited less known joints or even rent parties, sometimes asking African Americans for a kind of a guided trip around the Black district. ${ }^{48}$ But what did they think about the Black culture, about the idea of rent parties, about the everyday life in the ghetto? Let us finish with a quote from a book by Gilbert Osofsky:

At the very time Harlem was transformed into the city's worst slum, its image for most white Americans, and some Negroes as well, was just the reverse - a gay place inhabited by "a singing race" ... Had these people arrived at noon and inspected a rat-infested tenement, their image of Negro might have been changed; yet American racial consciousness refused to recognize any but the supposedly joyous side of Negro culture. ${ }^{49}$

44 L. C. Hubert, The Whites Invade Harlem, Library of Congress, p. 2; G. Osofsky, Harlem, pp. 181, 184.

45 L. C. Hubert, The Whites Invade Harlem, p. 2.

46 N. Williamson, The Rough Guide to the Blues, London 2007, pp. 40, 44, 49.

47 E. Latzman Moon, Untold Tales, pp. 260-261.

48 D. West, Amateur Night, MSS55715: BOX A725, Library of Congress, p. 2.

49 G. Osofsky, Harlem, pp. 150-151. 


\section{CONCLUSION}

While the Great Migration was meant to improve both the economic and social status of Black Americans, the reality was more bitter. After moving to Northern municipalities, the migrants usually found themselves in ghettos. Racial segregation (so-called Jim Crow's laws) was not officially present in the North, however, different divisions - not only racial, but also social or economical - existed in the everyday life. African Americans migrating from the South were forced to establish their identity among such groups as other ghetto-dwellers (including immigrants of European descent), so-called Old Settlers (Blacks living in the North for many decades) and the rising class of White, middle-income citizens.

However, the Black migrants found their own ways of coping with the harsh reality of the big-city life. As the will to pursue the American Dream met with social obstacles and Southern customs mixed with Northern opportunities, a whole new cultural movement began to flourish. Many families organised so-called rent parties, which soon became a kind of a trademark for the Black migrants; in New York a mini-revolution called the Harlem Renaissance took place; and in almost every city African-American musicians started to modernise jazz and blues music to make it sound more "urban." It was not long before the White citizens started to fancy this new culture and visit ghetto venues, which in turn led to even more far-reaching cultural changes.

The White public cared mostly about the joyous side of the Black urban culture, not really wondering about the economic or social situation of people by whom this culture was created. Nevertheless, now we know that its popularisation turned out to be crucial for the American culture as whole. Blues music slowly started to appear on the radio, small record labels, like Chess Records in Chicago, began to publish this so-called "race music" and later, in the 1950s, urban blues led to the birth of rock and roll and a new teenage revolution. Therefore, it is to be said that this rural-urban movement, dubbed the Great Migration, eventually changed not only the everyday life of a particular group but also the whole cultural landscape of the United States of America.

\section{BIBLIOGRAPHY}

\section{Primary Sources}

Burke, B., Elmer Thomas, MSS55715: BOX A707, Library of Congress.

Byrd, F., Harlem Rent Parties, MSS55715: BOX A721, Library of Congress.

Hubert, L. C., The Whites Invade Harlem, Library of Congress.

Swenson, M., Southern Customs, MSS55715: BOX A724, Library of Congress.

West, D., Amateur Night, MSS55715: BOX A725, Library of Congress. 


\section{Secondary Sources}

Bunch-Lyons, B. A., “"No Promised Land': Oral Histories of African-American Women in Cincinnati, Ohio," OAH Magazine of History 1997, vol. 11, issue 4, pp. 9-14.

Grossman, J. R., Land of Hope: Chicago, Black Southerners, and the Great Migration, Chicago-London 1991.

Latzman Moon, E., Untold Tales, Unsung Heroes: An Oral History of Detroit's African American Community, 1918-1967, Detroit 1994.

Lee, E. S., “A Theory of Migration,” Demography 1966, vol. 3, no. 1, pp. 47-57.

Lemak, J. A., "Albany, New York and the Great Migration," Afro-Americans in New York Life and History 2008, vol. 32, issue 1, pp. 47-74.

Osofsky, G., Harlem: The Making of a Ghetto, New York 1966.

Phillips, K. L., “'But It Is a Fine Place to Make Money': Migration and African-American Families in Cleveland, 1915-1929," Journal of Social History 1996, vol. 30, issue 2, pp. 393-414.

Robertson, S., White, S., Garton, S., White, G., "The Harlem Life: Black Families and Everyday Life in the 1920s and 1930s," Journal of Social History 2010, vol. 44, issue 1, pp. 97-122.

Scott, E., “Additional Letters of Negro Migrants," Journal of Negro History 1919, vol. 4, no. 4, pp. 412-465.

Trotter, J. W. Jr., Black Milwaukee: The Making of an Industrial Proletariat, 1915-1945, Urbana-Chicago 1985.

Williamson, N., The Rough Guide to the Blues, London 2007. 